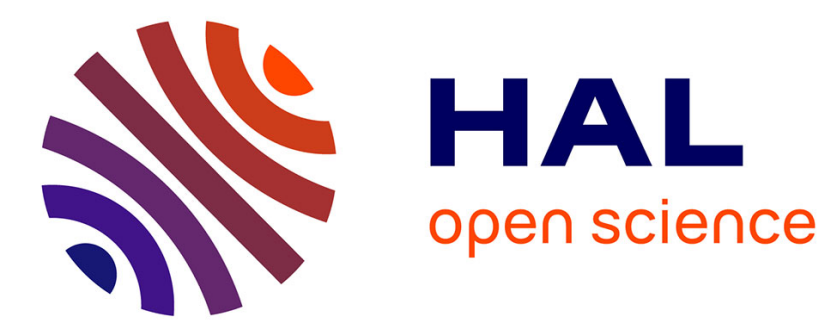

\title{
Overcoming the risks of restructuring through the integrative bargaining process: Two case studies in a French context
}

\author{
Pierre Garaudel, Florent Noël, Géraldine Schmidt
}

\section{- To cite this version:}

Pierre Garaudel, Florent Noël, Géraldine Schmidt. Overcoming the risks of restructuring through the integrative bargaining process: Two case studies in a French context. Human Relations, 2008, 61 (9), pp.1293-1331. 10.1177/0018726708094913 . hal-02441292

\section{HAL Id: hal-02441292 \\ https://hal.science/hal-02441292}

Submitted on 15 Jan 2020

HAL is a multi-disciplinary open access archive for the deposit and dissemination of scientific research documents, whether they are published or not. The documents may come from teaching and research institutions in France or abroad, or from public or private research centers.
L'archive ouverte pluridisciplinaire HAL, est destinée au dépôt et à la diffusion de documents scientifiques de niveau recherche, publiés ou non, émanant des établissements d'enseignement et de recherche français ou étrangers, des laboratoires publics ou privés. 


\title{
Overcoming the risks of restructuring through the integrative bargaining process: two cases studies in a French context
}

\author{
Pierre Garaudel, Florent Noël, Géraldine Schmidt \\ IAE Paris - Sorbonne Business School
}

\begin{abstract}
:
In this paper we analyse two French restructuring cases, using Walton and McKersie's theoretical framework, and provide evidence of the potential of integrative bargaining in restructuring. We argue that any restructuring situation, even in an unfavourable context such as the French, displays an integrative potential, in that employers' and employees' risks are closely interrelated and these risks can be successfully addressed in a cooperative way. The two cases are from widely contrasting contexts: a medium-sized firm in the declining textile industry, and a large insurance company with no short-term economic threat. We show to what extent the underlying bargaining processes are illustrative of an integrative approach as defined by Walton and McKersie and that such an approach may prevail in different kinds of situation, decline-related as well as competition-enhancing restructurings. Moreover, in reference with the four sub-processes developed in the Walton and MacKersie's model, we analyse how and under which conditions an integrative approach can be achieved. Finally, we discuss theoretical implications concerning the application of this model to restructuring processes.
\end{abstract}

\section{Introduction}

Restructuring literally means 'organizing something such as a system or a company in a new and different way' ${ }^{1}$. As an organizational change aiming at improving efficiency, restructuring should be viewed positively. At the firm level, modernization, technological progress and rationalization should lead to enhanced profits and durability; at the societal level, restructuring is supposed to lead to a better use of collective resources, and the development of new activities that will contribute to well-being (Friedman, 1970). However, 'restructuring' is commonly assumed to imply some kind of dramatic crisis rather than desirable change. In fact, organizational change is customarily termed restructuring only when workers are displaced, internally or externally (Cameron, Freeman \& Mishra, 1991). The term is commonly understood to signify workers threatened with job loss rather than firms for which change is a matter of survival or increasing profits. This perception is strengthened by the treatment of restructuring in the media, which focus on the 'victims'.

France is well known for its social conflicts. It is noticeable that, when French firms undergo restructuring, negotiation is typically confrontational, and restructuring is viewed as a fixed-sum game between employers and employees. Yet, in most cases, without restructuring, the future of the company would be in danger and drastic layoffs would invariably occur: in other words, if both parties fail to reach an agreement on the future of the company, they enter

\footnotetext{
${ }^{1}$ Oxford dictionary
} 
a negative-sum game, and the well-being of each is likely to suffer. This means that employers' and employees' risks are clearly linked during negotiations about restructuring.

The concept of 'integrative bargaining' first suggested by Walton and McKersie in 1965 throws some light on this process. In their seminal behavioural theory of labour relations, the authors define four sub-processes in social negotiation, including distributive and integrative bargaining ${ }^{2}$. Distributive bargaining aims at resolving pure conflicts of interest, in fixed-sum games situations; integrative bargaining aims at finding complementary or even common interests and solving the problems confronting both parties, resulting in a variable-sum game.

We suggest that restructuring can be conceived as a situation in which the interests of both parties are clearly integrated. The adoption of a purely distributive approach would result either in renouncing the necessary structural adaptations, or in the deterioration of the workforce's position, compromising the success of the operation, with the concomitant risk of embarking on a zero-sum game. The negotiators' chief concern is no longer to try to obtain the lion's share of the exchange, but to safeguard the restructuring operation as a whole, for the sake of enhanced collective value and utility. To this end, mastery of integrative bargaining is imperative to ensure the continued long-term development, and not just the survival, of the business.

In this paper we analyse two French restructuring cases, using Walton and McKersie's theoretical framework, and provide evidence of the potential of integrative bargaining in restructuring. Our two cases exemplify a collaborative approach to negotiations, rather than a series of confrontational events. This is remarkable in the French context, which does not normally favour such relationships and processes. The two cases are from widely contrasting contexts: the first is a medium-sized firm in the declining textile industry, and the second a large insurance company with no short-term economic threat. But despite their very different contexts and restructuring issues, an "integrative potential" existed in both cases, and contributed significantly to securing workers' individual trajectories as well as the required organizational change. This article throws light on the characteristics, outcomes, and facilitating and constraining factors of such integrative processes in bargaining about restructuring in an unfavourable institutional context.

We start by outlining the conceptual background based on Walton and McKersie's model and develop our research question: to what extent and under what conditions is it possible to achieve an integrative process when negotiating about restructuring? We continue by explaining our methodological choices and present our case studies. Our empirical findings are discussed through Walton and McKersie's model, to prove and explain their integrative dimension. Finally, we suggest that restructuring situations are potentially integrative processes, even in an unfavourable context, and may be achieved in several ways. Our focus on the bargaining process suggests a set of theoretical propositions and practical orientations to set against the existing literature on restructuring.

\section{Conceptual background and research issue - Restructuring as a risky confrontational event with an integrative potential}

In this section, we define the risks assumed by the different parties in the restructuring process, and present Walton and McKersie's conceptual framework. We will explain why, particularly in France, negotiating parties typically adopt a conflictual approach, which refers to a distributive logic.

\footnotetext{
${ }^{2}$ These sub-processes are parallel but not exclusive: they rather refer to different dimensions of the bargaining process that can even be mixed together or combined.
} 


\subsection{The accepted risks of restructuring}

Although some scholars argue that restructuring is not systematically detrimental to workers (Collett, 2004), it is more likely to worsen their condition, especially where labour markets are performing badly: displaced workers usually find themselves unemployed. Even when workers find another job immediately, they usually face earning losses through transition. According to Gazier (2005), in the European Union, only 57\% of displaced workers in the manufacturing sector will find another job within two years, and in the US workers typically face an earnings drop of $12 \%$. Moreover, workers are more likely to perceive their new job as being of lower quality. This perceived downgrading has negative consequences for job satisfaction and general attitudes (Feldman, Leana \& Bolino, 2002). There is long-standing evidence of other risks associated with job loss. Coping with layoff increases stress and associated negative outcomes, such as alcoholism, or deterioration in general health and family and social relations (Greenhalgh \& Mckersie, 1980; Leana \& Feldman, 1988). Even those workers who are not directly affected by restructuring suffer deterioration in well-being. This 'survivor syndrome', a mixture of guilt and feelings of insecurity, is particularly noticeable when restructuring is poorly managed (Amundson, Borgen, Jordan \& Erlebach, 2004; Appelbaum \& Close, 1999; Brockner et al., 1986; Sahdev, 2004)

Restructuring is risky for management as well. A wide range of literature has been produced demonstrating that firms fail to live up to their expected performance when they implement such changes (Cameron, 1994; Cascio, Young \& Morris, 1997). Several explanations have been offered for this. First, the costs of restructuring are often underestimated: initial cost and benefit calculations focus on the results expected from the shift in structures and do not integrate costs related to the restructuring process itself (Greenhalgh et al., 1980). Second, restructuring generates hidden costs that cannot be forecast. These costs may come from survivors' reactions, which affect their attitude and behaviour at work (Brockner et al., 2004; Brockner, Wiesenfeld \& Martin, 1995). They can also come from poor change management. For example, restructuring could damage internal networks and corporations' innovative abilities (Dougherty \& Bowman, 1995; Mone, McKinley \& Barker, 1998). Last, the image and reputation of restructured firms can be tarnished by the process, and affect sales and hiring (Karake, 1998).

Employers' and employees' risks are clearly interrelated: a large proportion of the risk assumed by management depends on the reaction of the workforce. The seminal research led by Cameron et al. (1991) has tried to provide managers with normative principles that could be implemented in order to foster effective restructuring. These principles exhort firms to manage restructuring in a proactive way that allows collective sense-making about the transformation and fair treatment of displaced workers. Cascio (2002) states that humane downsizing leads to effective downsizing because lowering worker insecurity also reduces the risk of hidden costs. Non-negotiated restructuring programmes are out of the question if these risks are to be avoided. The way in which negotiations are approached and handled is a determining factor of the outcome of the restructuring effort.

\subsection{The integrative potential of restructuring — Walton and McKersie's model}

Walton and McKersie's Behavioral Theory of Labor Negotiations (1965) is widely acknowledged as a prominent theoretical framework for examining the processes and outcomes of industrial relations negotiations. Strangely enough, even though the classical distinction between distributive and integrative bargaining is very often mentioned, studies integrating the various dimensions of this theoretical framework are quite scarce. More particularly, with very few exceptions (e.g. Pettitt \& Hanley, 2004), the Walton and McKersie 
model has almost never been used to analyse labour negotiations in a corporate restructuring context. The theoretical framework is based on the proposition that labour negotiations comprise four systems of activity, also referred to as four sub-processes of labour negotiations. The first sub-process is distributive bargaining, whose function is to resolve pure conflicts of interest. It is defined as the complex system of activities instrumental to attaining one party's goals when they are in basic conflict with the goals of the other party. The second sub-process is integrative bargaining, whose functions are to find common or complementary interests and solve the problems confronting both parties. It is defined as the complex system of activities instrumental to attaining objectives that are not in fundamental conflict with the objectives of the other party and which therefore can be to some degree integrated.

These two first sub-processes both relate to the content of the negotiation but differ as to the nature of the matters at stake. Walton and McKersie refer to matters pertaining to the distributive bargaining process as issues, while matters pertaining to the integrative bargaining are referred to as problems. The authors note that labour negotiations present few pure-conflict issues and few problems that allow both parties direct mutual gains. This leads them to envisage a third situation, involving both distributive and integrative bargaining, which is characterized as mixed bargaining.

In the following figures, the agenda is illustrated by reference to the utility frontiers that describe issues, problems, and mixed items respectively. Distributive issues are associated with a fixed-sum payoff structure where all points are pure conflict points, in the sense that all moves involve corresponding gains and losses (Figure 1). Integrative problems, for their part, are associated with a variable-sum payoff structure that contains a maximum integrative point, in the sense that any other point on the curve is clearly a worse position for both parties (Figure 2). Conversely, a mixed item situation is associated with a variable-sum payoff structure that contains a trading point that maximizes the joint gain: although either party could gain from moving to other points on the curve, these gains would involve disproportionately large sacrifices for the other party (Figure 3).

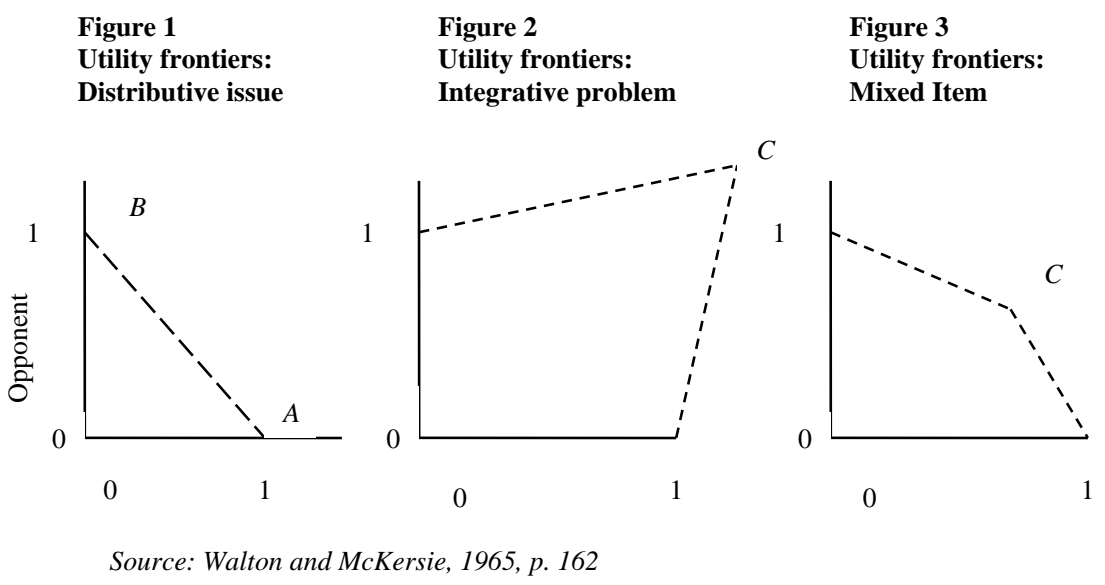

Besides integrative and distributive bargaining, which both refer to the nature of the agenda, the two other sub-processes identified by Walton and McKersie are attitudinal structuring and intraorganizational bargaining. The functions of additional structuring are to influence the attitudes of the participants toward each other and to affect the basic bonds that relate the two parties they represent. It is defined as the complex system of activities instrumental to the attainment of desired relationship patterns between the parties. The function of 
intraorganizational bargaining is to achieve consensus within each of the interacting groups. It is defined as the complex system of activities that brings the expectations of the principals into alignment with those of the chief negotiator.

The study of each of these sub-processes is itself of interest. Yet, to fully understand how the four sub-processes determine the characteristics and evolution of a negotiation process, they must be considered jointly. It is particularly necessary to look into the interaction between sub-processes and see how each of them impacts on the others. For example, attitudinal structuring and intraorganizational bargaining sub-processes may have significant repercussions on the propensity of chief negotiators to pursue either a distributive or an integrative strategy. In the same way, combining integrative bargaining and distributive bargaining in a same negotiation process is a difficult task, as each sub-process requires specific attitudes and negotiating strategies and tactics that may contradict each other.

When examining the risks of restructuring, the potential for integrative bargaining, as defined by Walton and McKersie (1965), seems to be high. Indeed, workers have an interest in the firm's profitability (or simply its durability), so that employment can be secured for the greatest number or because corporate and social performance may be intertwined (Orlitzky \& Schmidt, 2003). Conversely, the firm has an interest in taking care of its workers and securing their professional transition in order to avoid hidden costs and to preserve the firm's strategic potential. Some scholars have offered a wide range of alternative ways of restructuring that balance, on the one hand, the time horizon of cost saving or the rhythm of organizational change and, on the other hand, the protection of employees' well-being (Greenhalgh, Lawrence \& Sutton, 1988). This approach to restructuring has been documented since restructuring became a central theme of corporate life (Greenhalgh, Mckersie \& Gilkey, 1986). The scope and rhythm of change may be negotiated conjointly with the kind of trajectories and support that workers will be given as a consequence of the change.

However, it is difficult to opt for this kind of bargaining process in restructuring situations where parties are threatened by immediate and serious issues. And, in France, integrative bargaining is unlikely to be fostered by the legal and industrial relations context.

\subsection{The French classical bargaining process}

Although Walton and McKersie (1965) state that crises should foster cooperation, in France restructuring bargaining processes are launched too late and allow too little room for cooperative discussion. Confrontational relations are more likely to arise, even if the French legal framework is, in the letter of the law, perfectly in line with the recommendations outlined above. The strict application of labour laws should lead to cooperative restructuring. However, the way social partners use this framework usually leads to confrontation and hampers any kind of integrative behaviour.

From a risk management perspective, French employers are required to inform the members of the works council about any event or decision that may affect the workforce or work processes. Furthermore, when restructuring is being considered, a two-step consultation process is required by law (Ray, 2007). The first step is organizing a discussion about the cause. This cause has to be 'real and serious' and must be related to economic matters. In this discussion, union representatives can be supported by chartered accountants in order to have access to neutral information. The second step is discussing the implementation of the restructuring scheme and focuses on alternatives to redundancy and social packages for laidoff workers.

Unfortunately, the nature of French industrial relations impedes the smooth application of this legal framework (Andolfatto, 2004). First, the ideology shared by the social partners (both employers and unions) is still infused by the class-struggle principle, so that discussion 
is hampered. As a result, the obligatory two-step consultation process fails to act as a driver for compromise or formal agreement (information sharing is required, not agreement). Second, the works council is an elected body, but its members have a strictly consultative role and are not allowed to sign agreements. Union representatives within the company can sign agreements, but they are unelected. Forty years ago, a decree allowed five 'representative' unions to sign agreements with a company, regardless of the size of their membership, although management is likely to privilege the powerful unions among the workforce as negotiating partners. As a result, unions compete with each other within negotiations, which can lead to an escalation of claims. Furthermore, agreements are unstable, as non-signing organizations may not feel constrained. The competition between the Confédération Générale du Travail (CGT) and the Confédération Française Démocratique du Travail (CFDT) should be noted. Although times have changed, the CGT is still more or less infused with its communist tradition and inclined to denounce any kind of compromise with employers. The CFDT has a social democrat tradition that has resulted in a greater tendency to accept reforms (Andolfatto, 2004). The CFDT often leads the bargaining process, if there is one, while the CGT pressurizes employers using confrontational methods (both these tactics sometimes tacitly complement each other). Meanwhile, contractual terms cannot be less favourable to workers than the law allows. There is therefore little incentive for employers to become involved in a bargaining process that can only result in a lowering of their position.

In this general context, it is difficult to implement bargaining processes in France, and partners are inclined to negotiate in a way that is more ceremonial than instrumental. When bargaining is about restructuring, the situation is worse. The two main obstacles arise on the unions' side. Usually, the list of displaced workers is revealed at the very end of the consultation process, after examining the motive for restructuring and the social plan. Moreover, unions that have to stabilize their competitive position inside the company usually prefer not to participate in the economic discussion, nor to discuss the criteria used to select displaced workers (Colin \& Rouyer, 1996). It is easier to consolidate workers around a common feeling of insecurity that affects the entire workforce and avoid negotiation that could be interpreted as compliance. That leaves little room for examining the positive side of restructuring. The second obstacle is that, in a context where agreements are not required and unions are dispersed, unions are inclined to use the labour court to resolve disputes instead of negotiation. The judge will then appraise the validity of the restructuring, on the basis of the veracity of the cause, the appropriateness of the social plan proposed by management and respect for the procedure. The final verdict is likely to be binary, either validating or cancelling the entire process. This pattern of dispute resolution does not lead to improvement in cooperation and the finding of integrative solutions. On the contrary, it is related to a conflict resolution model, stating who is right and who is wrong, whose project will be validated and who will lose. Employers are left in a very insecure position (Ray, 1995), which drives them to decide unilaterally on the restructuring plan, considering the balance of power and jurisprudence, rather than opening effective negotiation.

Of course, it is not just the French who find negotiating reconstruction difficult. Social partners often fail to consider restructuring as an opportunity to discuss the future of the organization and the future of workers, both inside and outside the organization. Strategy and employment are not usually considered issues for debate. In the United States, as a result of the employment-at-will principle (Radin \& Werhane, 2003), unions and workers are informed when decisions are made. The only possible tactic for trades unions may be to try to block the entire process or to bargain the amount of compensation rather than address the issues behind restructuring. On the other side, management may prefer to decide on the economic and organizational project and consider the reactions of the unions and individual workers as nonnegotiable costs to be borne. Depending on how power is balanced between social partners, 
the result of bargaining falls somewhere on a continuum ranging from complete ignorance of workers' expectations to organizational inertia. The threat of confrontation may also lead firms to prefer processes that do not require any negotiation (such as workforce attrition) or are more popular, such as early retirement, even if they are expensive and hold up the process of restructuring. But avoiding direct confrontation can also make firms opt for methods that are not so beneficial to workers, such as incentives to quit, or temporary contracts or subcontracting. In those cases, the responsibility for easing transition is transferred to the workers or the community.

\subsection{Research objectives}

Negotiations about restructuring are usually conflictual and reflect the adoption of a distributive approach. This approach carries significant risks for both employers and employees: if the future of the company is not considered as a common good, then the risk is to enter a negative-sum game that will reduce the well-being of both company and workers. We therefore argue that any restructuring situation displays an integrative potential, insofar as employers' and employees' risks are closely interrelated and the risks can be successfully addressed in a cooperative way. This integrative potential exists even in non-favourable institutional contexts, like France. Our research question is: to what extent and under what conditions is it possible to achieve an integrative process when negotiating about restructuring?

In the next section, we look at two case studies of French firms that have managed major restructuring, and we show to what extent the underlying bargaining processes are illustrative of an integrative approach as defined by Walton and McKersie. We present evidence that this approach will be equally successful in different situations, decline-related as well as competition-enhancing restructurings. Finally, in reference to the four sub-processes developed in the Walton and MacKersie model, we analyse how and under which conditions an integrative approach can be achieved when negotiating about restructuring.

\section{Method and case narratives-AXA and ECCE, two cases of secured restructuring in the French context}

\subsection{The empirical study: context and methods}

\section{The European MIRE project}

Our empirical study is based on studies of two companies, AXA and ECCE, carried out between 2005 and 2007 as part of the MIRE Project. MIRE (Monitoring Innovative Restructurings in Europe) is a European research programme funded by the European Social Fund and coordinated by Syndex consultants who specialize in accompanying works councils. The project consists in capitalizing on innovative approaches that are respectful of the interests at stake. It aims to allow 'the appropriation of these innovative practices through exchanges between the different actors concerned by restructurings (companies, salaried workers, public authorities and territorial authorities) in the different countries taking part in the project (Germany, Belgium, France, the United Kingdom, Sweden)' . 3

Our research centre took part in this project along with three other French research teams, producing restructuring case studies that informed the thinking of a group of experts who were to discuss them. It gathered several European research teams from Sweden, Belgium, the

\footnotetext{
${ }^{3}$ From the working document established to present the MIRE project to the research teams concerned.
} 
UK, Germany and France, and it aimed at spotting 'innovative practices' of restructuring and discussing their transferability between companies and countries. In each country, a group of professional experts discussed the innovative nature of the cases and then carried out crossanalyses to derive more general conclusions and recommendations. These experts were representatives of the various stakeholders: some were unionists or union advisers, others were human resource managers or members of the French employers' association (MEDEF); they came from national or regional public employment services, or were consultants involved in restructuring issues such as territorial revitalization or outplacement.

The case selection method

The definition of 'innovative restructuring' has been the subject of much debate in national and international workshops within the MIRE programme. The criteria used to hypothesize ex ante that these cases were innovative all converged towards a definition where usual national problems were overcome. As far as France was concerned, the main issues raised by the experts were anticipation and social dialogue. This led us to select cases that had been managed in a consensual climate (with no major conflict), as they were framed by collective agreements. Ex post, the participants we interviewed systematically acknowledged the mutual trust and respect shown by all parties, indicating that a strong positive attitude within an integrative bargaining process (Walton \& Mckersie, 1965) had been developed in continuous negotiation throughout the restructuring operation. They both testified that the situation could have been much worse, and seemed proud of what had been achieved ${ }^{4}$. AXA and ECCE were selected from the others because we considered they had been managed in a collaborative social climate, leading to well accepted results in terms of securing individuals' trajectories and organizational change.

The field research and data collection

MIRE's decision to observe innovative practices in restructuring obviously has implications for strategy and research methodology. On the one hand, it undeniably facilitated access to the field. On the other hand, the decision partially oriented the research issue, our initial questioning and even the profiles of people encountered. We were therefore particularly careful to choose a variety of people to interview (especially those who kept away from the bargaining process), to collect documents from various sources and channels and to keep a critical attitude toward the supposed 'success' of the restructuring.

For each case study, several pieces of information were collected, and a qualitative analysis was carried out. This mainly consisted of performing semi-structured interviews with different participants, and collecting documents about the restructuring decision, process and implementation. More precisely, we collected a set of documents shared by all participants: the official justification of the restructuring plan, detailed accounts of work council meetings, the Steering Committee's scorecards, and many press articles. Face-to-face interviews were performed for each case (22 at ECCE and 21 at AXA), specifically with the main actors, those who were involved in the bargaining process (managers and union representatives), those involved in the implementation process of the restructuring (HR managers, employees, unionists, consultants), and also more generally with people or institutions more or less directly concerned by the restructuring decision, its process and effects. The average duration of each interview was 90 minutes. Because interviewees were likely to be reluctant to answer our questions freely on such a sensitive subject, we decided to make a written record of their answers rather than record them. These interviews and documents were then synthesized into case study reports relating the events with as little interpretation from the researchers as possible. These case studies were then submitted to the group of experts and to the main actors involved in the process to ascertain their factual reliability. This methodological

\footnotetext{
${ }^{4}$ This also explains why we had such in-depth access to the field to carry out our qualitative investigations.
} 
process, following Eisenhardt's $(1989 ; 2007)$ suggestions for writing case studies, eventually provided the empirical material on which the present analysis is based. The context and content of the cases are detailed below.

\subsection{Restructuring's context and content at ECCE and AXA}

ECCE presented a situation of long-term decline, whereas the core issue for AXA was internal, entailing qualitative and quantitative flexibility at corporate level. As for the restructuring type or content, ECCE was an example a firm needing to make drastic job cuts and downsize, while AXA had to make job adjustments, with a stress on occupational mobility. The respective strategic context, the central orientation of the restructuring plan and the nature of dialogue between social partners at ECCE and AXA are described below.

\section{ECCE's strategic context: a medium-size firm in a declining industry}

ECCE is a medium-size company in the north of France that has grown from successive reorganizations of a major clothing group and is now controlled by a single shareholder. ECCE was confronted with the same difficulties as the whole French textile industry, as manufacturing moved in bulk to low-wage countries. ECCE's business is to negotiate licences with famous couture houses in the luxury menswear sector and then develop, manufacture and sell men's suits based on models designed by these couture houses. It is a unique niche, but highly dependent on the couture houses. Our case study focuses on the way ECCE handled the decision by two major houses, YSL and Kenzo, not to renew their licence agreement, which represented nearly $70 \%$ of ECCE's turnover. At the end of 2001, the restructuring plan was officially announced, and the future of the whole company was threatened. This involved the production site (400 people), the head office (200) and the logistics area (130). The restructuring 'cause' was clearly identified and consensually accepted, and qualified as both economic and external.

\section{Content of the restructuring plan at ECCE: a French classical 'severance package'}

The restructuring plan was a classic French severance package including severance pay (up to 11 months of salary, depending on seniority), and outplacement support for one year. But the firm also proposed a set of actions aimed at fostering local economic development, something it was not legally bound to do. Given its industry sector and size, ECCE's plan was particularly generous, comparable to those of big multinational companies. The social plan was innovative in its process and implementation, especially in terms of the outplacement process and the high involvement of stakeholders.

Nature of the social dialogue

Discussions between social partners at ECCE initially concentrated on the necessity of closing down the plant. Union representatives urged top management to consider all other alternatives. All parties formally agreed that consensus on the industrial future of the company was needed before a layoff plan could be carried out. They signed a 'method agreement', the general purpose of which was to plan the stages of future negotiation. It included, for example, the possibility of resorting to independent experts (for collecting information, addressing the industrial issues, etc.) and to a mediator. The process took over 18 months before the restructuring could begin. AXA's restructuring plan differed significantly.

AXA's strategic context: evolving activities and better productivity

In 2000, the insurance giant AXA France faced a crisis in production efficiency, which management judged to be unsatisfactory. Although the company was economically healthy, it was nevertheless necessary to improve internal functioning in terms of organization and HR management, after a long period of repeated external growth operations. Consequently, to 
differentiate AXA France from its competitors in terms of quality of customer service, the company chose to redirect its labour towards commercial tasks, leaving administration to an increasingly efficient IT system.

AXA's strategic choice for restructuring: internal mobility

AXA rejected the idea of collective redundancies for a number of reasons. It would have been difficult to justify in legal terms and excessively costly. AXA also wanted to remain faithful to the tradition of social progress and economic modernity that its founders had emphasized from the beginning, in sharp contrast to the immobility ingrained in French insurance companies. Management decided instead to concentrate on internal mobility. Nobody has been made redundant, and recruitment has been restricted to filling posts that cannot be developed from among the existing workforce. Independently of these internal adjustments, AXA has let the workforce reduce through a process of natural attrition. This restructuring plan was formalized in the company's Cap Métiers agreement.

\section{AXA's Cap Métiers plan}

The plan is mainly focused on accompanying workers throughout their professional trajectory, including orientation counseling, training and integration into new teams. The transition is secured through the preservation of wages and status - even in the case of under qualification - and by a reversibility clause. Volunteering and the matching of individual aspirations to organizational targets are favoured by strong internal communication and the implementation of 'Invitation to Change' training programmes.

The social dialogue at AXA: mobility in exchange for job security

The agreement between management and unions was clear: management was free to make the necessary organizational changes and, in exchange, committed itself not to lay off personnel and not to shut down production sites. Adjustments were made only for internal mobility. For this purpose, the official agreement considered the means to promote mobility (professional guidance, training, tutoring, information, etc.) and guaranteed the principles of voluntary participation, confidentiality and reversibility for individuals. In total, four unions (CFDT, UDPA, CGC, CFTC) out of six signed the agreement; the CGT and FO refused, although no significant action followed. In short, while the union representatives never officially recognized the necessity of the reorganization, all parties acknowledged that entering into formal restructuring patterns would have radicalized the position of the unions and frightened the employees, making them less inclined to accept changes.

While there was a great contrast between the strategic context and the contents of the restructuring plan at ECCE and AXA, they had several things in common as far as restructuring methods and general results were concerned. Indeed, there were several striking similarities in the restructuring process, in particular a process around consent to the strategic vision of the firm, and a process securing individual trajectories.

At AXA, strategic change is at least implicitly accepted by both managers and employees, and has led to a dramatic qualitative shift in the workforce and to staff reduction through internal mobility. At ECCE, the process of agreement around the corporate strategic vision is less obvious but no less real. Managers remain committed to the company's survival and want to maintain a minimal activity in France: this requires looking for new businesses (women's ready-to-wear), for more added-value (decreasing production time, prototypes, etc.) and for less demanding contractors. But at the same time management will agree only to maintain business in trade and logistics without planning further investments. 
Similarly, we can observe a process of securing individual trajectories in both cases. At ECCE, the agreement includes measures like short-term outplacement and bonuses, long-term validation of job experience, securing a job in the new organization, equipping individuals for the labour market, making the local labour market more dynamic, etc. At AXA, the internal mobility incentive policy is based on voluntary participation and is largely secured by orientation, training and integration schemes, a reversibility clause, and a clause guaranteeing salary and status.

Table 1: Summary of the two cases

\begin{tabular}{|c|c|c|}
\hline & AXA & ECCE \\
\hline Interviewees & $\begin{array}{l}\text { HR management (4), operational managers (5), } 2 \\
\text { union representatives (CGT and CFDT) including the } \\
\text { secretary of the works council, } 9 \text { employees, } 1 \\
\text { consultant }\end{array}$ & $\begin{array}{l}1 \text { VP in charge of operations and HR management, } \\
1 \text { plant manager, the secretary of the works council, } \\
1 \text { mediator, } 11 \text { employees ('survivors', most of them } \\
\text { members of the works council), } 2 \text { independent } \\
\text { experts, } 3 \text { members of the outplacement service, and } \\
2 \text { representatives of local authorities }\end{array}$ \\
\hline Documents collected & $\begin{array}{l}\text { Signed agreement, Cap Métiers plan, communication } \\
\text { support from unions and from management, } \\
\text { assessment documents }\end{array}$ & $\begin{array}{l}\text { Works council sessions minutes, method agreement, } \\
\text { experts' reports, mediator's reports, official } \\
\text { documents on the collective dismissal procedure }\end{array}$ \\
\hline Strategic context & $\begin{array}{l}\text { A leading firm in the insurance sector } \\
\text { Search for better productivity following several } \\
\text { mergers and acquisitions } \\
\text { Evolving nature of the insurance activity }\end{array}$ & $\begin{array}{l}\text { A medium-size firm in the declining textile industry } \\
\text { High dependence on two couture houses about to } \\
\text { terminate their contracts } \\
\text { Initial plan to close down the plant }\end{array}$ \\
\hline Bargaining method & $\begin{array}{l}\text { Strategic issues are not debated by the parties } \\
\text { Discussion focuses on organizing internal mobility }\end{array}$ & $\begin{array}{l}\text { A 'method agreement': the parties agree upon } \\
\text { exploring strategic alternatives before layoffs }\end{array}$ \\
\hline Restructuring content & Internal voluntary and accompanied mobility plan & A classic French 'severance package' \\
\hline Securing corporate project & $\begin{array}{l}\text { Strategic change is no longer taboo } \\
\text { Restructuring is implemented } \\
\text { Results reach an unexpected level }\end{array}$ & $\begin{array}{l}\text { Closure is delayed } \\
\text { Restructuring is achieved with no disruption of } \\
\text { production } \\
\text { Strategic targets are identified }\end{array}$ \\
\hline $\begin{array}{l}\text { Securing individual } \\
\text { trajectories }\end{array}$ & $\begin{array}{l}\text { Job and earnings are maintained } \\
\text { Internal mobility is viewed as career opportunity }\end{array}$ & $\begin{array}{l}\text { Closure is delayed } \\
\text { Employability is developed for future transitions } \\
\text { Support is provided for laid-off workers }\end{array}$ \\
\hline
\end{tabular}

Beyond their common features, it can be argued that both processes led to outcomes that could be considered integrative, according to Walton and McKersie's definition.

\section{Asserting and explaining the achievement of an integrative outcome - theoretical discussion of case studies}

In order to account for the integrative outcomes observed in the AXA and ECCE cases, the following sections adopt the Walton and McKersie framework for analysing the strategies pursued by the parties and their effective outcomes (3.1.), and also the factors that facilitated or, conversely, impeded the development of an integrative approach (3.2.). Finally, we outline two different ways to achieve integrative outcomes while bargaining about restructuring (3.3.).

\subsection{Some integrative outcomes in both cases}

It is difficult to hypothesize what would have happened if the social partners had not been able to find a path to restructuring that could secure both strategic development of the company and individual transitions. However, using the past experiences of these companies as benchmarks, we can assert that AXA and ECCE's restructuring led to integrative outcomes.

ECCE is the relic of a large group, Bidermann, which until the early 1980s employed up to 8000 workers. Since then, the group has shrunk through off-shoring and divestment of activities and production units. Over several decades, union representatives had to fight to 
have their rights acknowledged by a management that was infused with an authoritative and paternalist mentality. According to union representatives, this confrontational approach, which owed much to the union methods developed in the steel industry, led to substantial outcomes. An effective work council was established and some planned sell-offs were cancelled. The last major incident of industrial action took place in 1986, when management decided to close a plant in Valenciennes in northern France. Workers blocked the factory and organized violent strikes. It was a losing battle: some jobs were saved but relocated to another unit at Poix du Nord ${ }^{5}$, and most of the workers were laid-off. At Poix du Nord, management threatened to declare bankruptcy in order to carry out the planned closure. A few years later, Bidermann collapsed, unable like many other textile companies in France, to compete with low-cost countries. Bidermann was bought by a private investor for a symbolic one franc. Its men's suiting unit was renamed ECCE.

AXA also had to restructure constantly. The company has been developing through external growth for about 20 years. Every merger and acquisition caused overstaffing that had to be dealt with. However, as a wealthy and powerful company, AXA could not even begin to think about launching a major collective layoff plan. This would have triggered a major conflict and very possibly have been cancelled by the labour court, for lack of compelling motive. They opted for a continuing early-retirement policy, allowing workers to leave at 56. Over the years this policy came to be considered as a social benefit granted by management to workers; it could hardly be stopped. The policy meant that many workers who might otherwise have been made redundant were placed in positions in which there was little to do, waiting to reach 56 . This was costly for both management and workers, but more comfortable than leaving the company or moving to another position. This process of natural attrition was a painless way to cut jobs but adaptations were not happening as quickly as required. By the beginning of the $21^{\text {st }}$ century, the process was outmoded: early retirement was less and less tolerated by the French labour administration and the legal age for retirement was raised.

Although these two situations are clearly different, they illustrate outcomes where one party is able to dictate the rhythm and method of restructuring to the other. At ECCE, restructuring decisions and implementation were the result of conflict between management and unions, while at AXA, management preferred to avoid a confrontation that would probably be lost. Using Walton and McKersie's utility frontiers (1965, p. 162) is helpful to characterize the outcomes of these processes and assert their integrative nature. In this context, we assume that the perceived utility of restructuring for the workers will depend on their level of job security and compensation, while the perceived utility for management will depend on the extent and rapidity of the adaptation of the measures to their needs. We refer here to the dimensions identified by Greenhalgh et al. (1988), which classify restructuring methods on a sliding scale between the extremes of individual well-being and the organization's speed of adjustment. As seen in Figures 4 and 5, the balanced outcomes achieved in past restructuring experiences depend on a negotiated compromise between their utility for workers and management.

\footnotetext{
5 The little town were ECCE has its last production unit.
} 
Figure 4. Restructuring past experiences at ECCE: management overcomes union resistance

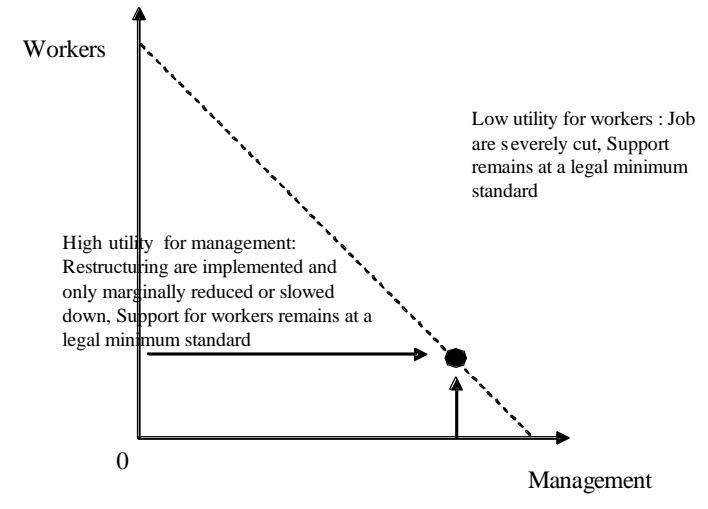

Figure 5. Restructuring past experiences at AXA: management

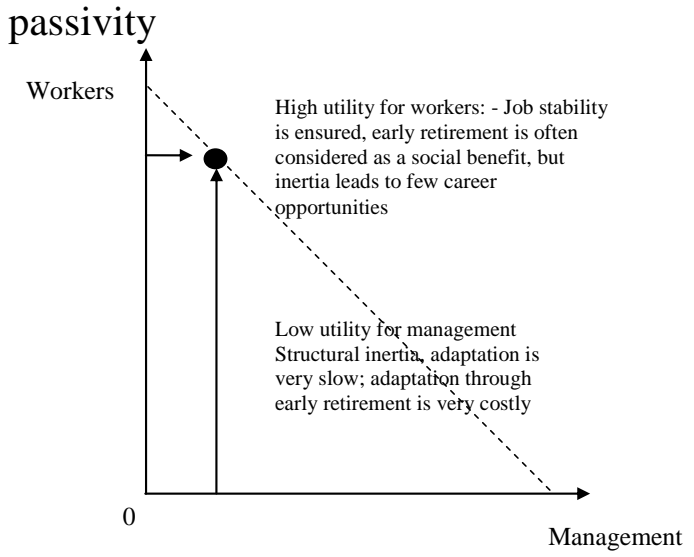

These balanced outcomes assume that management want restructuring and the unions don't. However, another way to consider restructuring is that it is required to ensure corporate performance and a future for the company, which should be in the interests of both parties. This conciliation between both sides' objectives is clearly what has been achieved in the two restructuring cases analyzed here.

Considering only outcomes, in both cases, restructuring was achieved so that production did not suffer and no major dysfunction was identified. ECCE was able to guarantee haute couture houses continuity in delivery and preserve of their reputation. As a result, one major contract of the two announced to be terminated was renewed. Moreover, AXA and ECCE could implement adaptations of their structure without suffering any deterioration of their image and reputation. ECCE's plant at Poix du Nord was reduced in order to fit the new level of production and AXA managed a drastic reduction in workforce through natural attrition without having to hire new skilled workers. The internal transitions worked well, so that the new client-oriented organization could be implemented. All the organizational changes at stake were processed satisfactorily.

The restructurings were also managed so that workers were given security. Of course, some workers lost their jobs at ECCE, and some workers were displaced at AXA. But, at ECCE, job cuts were reduced and workers benefited from opportunities to develop their own employability. This meant that they could be employed in a different position internally or reskilled to ease their transition to other companies or other professions. At AXA, workers benefited from the guarantee of job continuity and preservation of status and the volunteering rule meant that no one was forced to move. Interviewees from both sides recounted the favourable changes they experienced, taking advantage of training and mobility to take a new step in their professional and sometimes personal life.

It is possible to illustrate the integrative nature of these two restructuring processes by using the same utility frontiers framework and measuring the extent to which these two restructuring processes facilitated the simultaneous increase in utility for both parties. Taking events in the past as a reference point, it is possible to appraise to what extent utilities evolved.

At ECCE, management was particularly pleased to be able to carry out restructuring while maintaining production until contract termination. On the workers' side, the unions considered the adoption of the new strategy and employability enhancing policies as a victory over managerial defeatism. Union members underlined that the time between the notice and the implementation of layoffs was highly valuable, since it was possible to anticipate layoffs using massive training and job-experience validation programs negotiated as part of the generous social package. This period was considered an opportunity to ease professional 
transitions. From both management's and workers' points of view, restructuring is clearly utility destructive, but utility is maintained at a higher level than past similar experiences.

At AXA, both parties seem to have benefited from the restructuring process. Managers had not imagined they would be able to change the structure so radically. The operation was hailed as the end of an era of inertia and deeper changes can now be implemented. On the workers' side, we found no sign that some employees felt they had suffered from the restructuring. On the contrary, many interviewees from both sides, workers included, underlined the positive impact of transition for individuals. We can assume that restructuring created net value for both sides.

Figure 6: Utility Frontiers: Integrative experience at ECCE

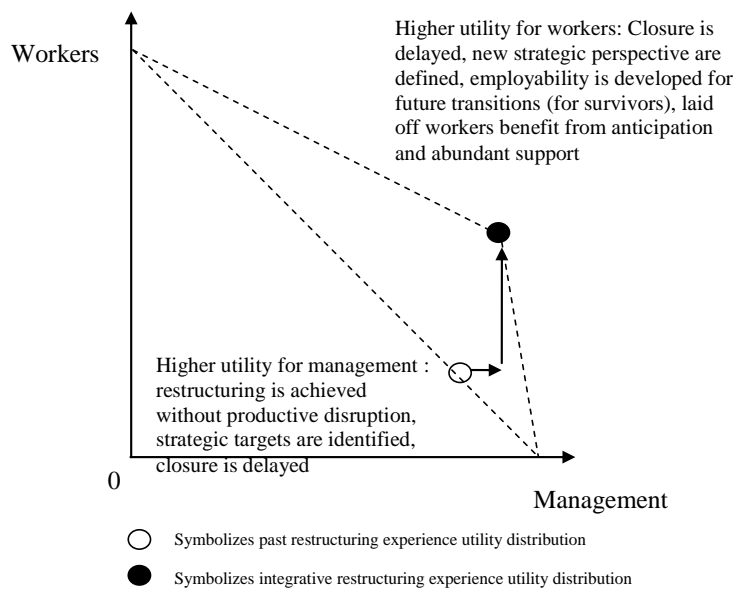

Figure 7: Utility Frontiers: Integrative experience at AXA

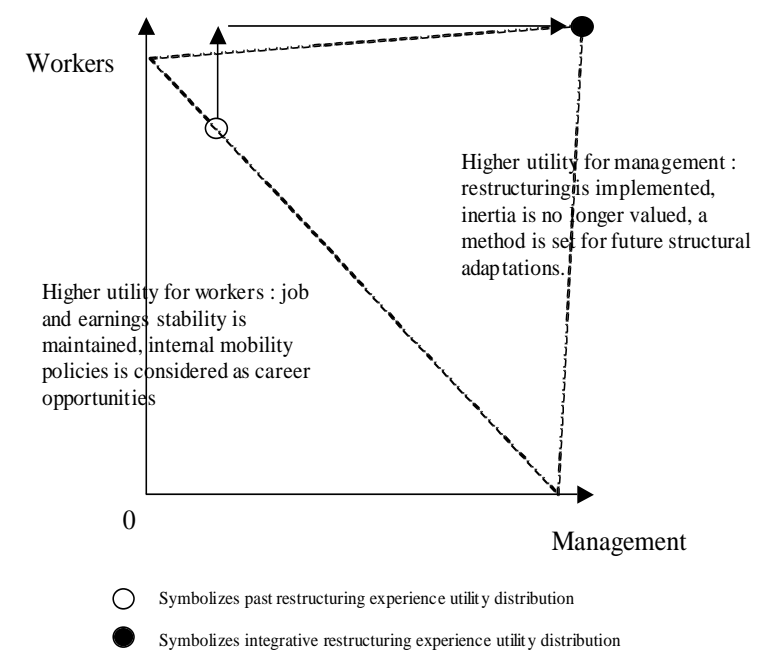

Beyond utility appraisal, other indicators confirm the integrative nature of the outcomes of these two bargaining processes. First, the perceptions of actors remained positive throughout the process and continued when it was over. In AXA and ECCE, negotiators felt proud of the work done in common and testified trust in the other parties at the end of the restructuring. We can assume that the result of the bargaining was mutually beneficial. This is reinforced when considering the opinion of workers at AXA. They declared that the internal mobility 
process was highly protective. The popular success of this process, based on free will, is a sign of its success in addressing people's needs and expectations. Second, we found a relative absence of distributive activities during these processes. Power, conflict and strikes were kept at a minimum. Both processes were covered by a formal agreement (about the whole process at ECCE, about internal mobility at AXA). This propensity to contract about restructuring is uncommon, especially in France (see above) and indicates a certain degree of mutual respect and shared understanding. Last, the unions participated actively in the contract administration, which suggests that contracts were satisfactory and that attitudes toward management and restructuring remained positive. Indeed, at ECCE, trade unions played a decisive role in easing the social climate and implementing the social plan and outplacement activities. They also emphasized that workers needed to become involved in the employment-enhancing programme based on the validation of work-derived experience. At AXA, the CFDT communicated actively on the positive aspects of internal mobility making sure it was seen as a career opportunity and not just a way to reallocate the workforce. Interestingly, they also applied for an extension of the Cap métiers mobility programme, so that everyone could feel included in the general process.

These two cases demonstrate that, even in the French context, and even when firms are facing critical situations, restructuring can be negotiated and implemented in a way that integrates the interests and objectives of management, unions and workers, securing individual trajectories for employees as well as the organizational change required for the companies. However, integrative outcomes come from the deployment of a wide set of bargaining activities, which we will now discuss.

\subsection{Enabling and constraining integrative outcomes}

We will examine the conditions that facilitated the adoption of an integrative approach, as well as the factors that make the process difficult and which, as a rule, tend to prevent negotiators from fully engaging in an integrative bargaining process.

\subsubsection{The presence of several factors increasing the parties' propensity to engage in an} integrative bargaining process

\section{The crisis-related factor}

Walton and McKersie suggest that a more cooperative approach may be fostered if the circumstances are critical. They note that, on many occasions, management and labour enter into cooperative programmes to save the company and employment. This crisis-related factor undoubtedly played a major role in the ECCE case. The seriousness of the situation was acknowledged by all the parties. Moreover, the factor that triggered the difficulties - the prospect of a sharp drop in turnover following the decision of some couture houses to terminate their license agreement with ECCE - was clearly identifiable and was perceived as external to the company. It could also be argued that the specificity of ECCE's business activity, which involves a strong dependence on the fashion houses, had contributed to the development of a sense of solidarity between two parties facing a threatening and unsteady environment and that may be directly affected by decisions taken by few external decisionmakers. In this respect, the familiarity of employees with the constraints associated with the licence system is illustrated by the frequent discussions at the work council meetings (as recorded in the minutes of the meetings) about the contract negotiations with fashion houses and canvassing activities. As for AXA, there was no economic crisis: the company was in a healthy financial situation. On the other hand, it may be argued that this favourable economic context not only contributed significantly in the decision not to implement a redundancy 
programme but that it also explains the distinctive features of the negotiation process discussed below.

The time factor

A potentially critical dimension of labour relation negotiations consists in the time negotiators have at their disposal to reach an agreement. An integrative bargaining approach may take time, as it requires searching for and appraising alternative solutions as well as surmounting the many difficulties inherent in the process of reconciling various parties' interests. This time factor may be all the more important in a crisis context, when time pressure motivates the actors to confront the situation by making prompt decisions. In this respect, time pressure could have been a serious impediment in the ECCE case, considering the radical nature of the events that led the parties jointly to address the problem of overstaffing. In fact, the time pressure was not so high since the termination of the most critical licence agreement was due to take effect two years after its announcement. Management could therefore afford to take time to negotiate, which allowed the parties some breathing space to engage in a problemsolving process. This propitious factor is reflected in the negotiation timetable scheduled in the Method Agreement previously signed by the parties. The planned timetable was flexible and relatively long. The duration of negotiations - nearly 13 months passed between the signature of the Method Agreement (29 April 2002) and the signature of the Social Plan (20 May 2003) - was even longer than envisaged in the Method Agreement.

Attitudinal structuring

The most common if not essential facilitating condition in both cases is related to the 'attitudinal structuring' sub-process. Walton and McKersie's third sub-process determines the propensity of parties to adopt an integrative bargaining approach. The key concept of 'relationship pattern' is defined as a set of reciprocal attitudes salient to the way in which they interact. It results from the combination of: (1) motivational orientation and action tendencies toward each other (competitive-individualistic-cooperative); (2) beliefs about the other's legitimacy, (3) feeling of trust toward the other, and (4) feeling of friendliness-hostility toward the other (Walton \& McKersie 1965, p.185). Based on these different dimensions, they propose a classification scheme distinguishing five types of relationship patterns: conflict, containment-aggression, accommodation, cooperation, and collusion. Among these, as we will see in more detail below, the cooperative type of relationship pattern is clearly the most appropriate to describe what we observed in our case studies. This is of importance since, as Walton and McKersie stress, attitudinal structuring is not an activity that merely parallels other negotiation processes; it interacts with distributive and integrative aspects of negotiations in several vital ways. More specifically, it may be argued that the prevalence of a cooperative type of relationship pattern favours the adoption of an integrative bargaining approach by all parties.

Walton and McKersie note that the motivational orientation is cooperative and that there is full respect of the other, mutual trust and generally a friendly attitude between the parties. These distinctive features of the cooperative pattern apply to both our case studies. Thus, especially during interviews for the ECCE case study, interviewees from both management and union sides spontaneously emphasized the positive climate that had prevailed in the negotiations, as well as the feeling of mutual trust and respect that grew between the parties. This cooperative attitude may itself be explained by many of the determinants of relationship patterns put forward by Walton and McKersie, such as those related to personality factors or social beliefs.

The ECCE chief negotiators had known each other for a long time and were used to working together. More specifically, the management chief negotiator had long shown his attachment to social relations within the company and had in the past proved to be a reliable 
social partner. What is more, he benefited from the support of the company's sole shareholder; the latter had been involved in institutional activities and had clearly expressed a strong desire to avoid social conflict. For her part, the chief union negotiator showed good knowledge of economic and industrial issues and, far from being dogmatic, had always been open to negotiation. It should also be noted that she was the leader of the CFDT section in the company. This is important as the CFDT is, among the French unions, generally considered to be the most open to negotiation.

A number of similarities can be drawn with the AXA case. The AXA management has long publicly prided itself on the company's commitment to its employees. The majority union was also affiliated to the CFDT, which is perhaps an even more decisive factor with regard to the more complex union landscape of such a large company as AXA. The leading union negotiator typified the labour relations approach promoted by the CFDT. In our interview with him, he insisted on the necessity of reaching negotiated agreements, even on sensitive topics such as employees' internal mobility, arguing that the management will otherwise, in some way or another, try to act in their own way leaving no possibility for the unions to control and influence the process and impose safeguards. It must be stressed that the content of the negotiated agreement hints by itself at the cooperative nature of the relationship pattern. According to Walton and McKersie, the cooperation pattern is characterized by the fact that the parties willingly extend mutual concerns far beyond the familiar matters of wages, hours, and conditions and that, correlatively, production efficiency, the solvency of the firm, reduction of waste, advanced technology, employment security, and so on are treated as matters of common interest. Moreover, one of their general proposition is that, as parties move from the competitive end to the cooperative end of the relationship spectrum, they tend increasingly to confine distributive bargaining to the areas of inherent conflict, e.g. economic items, and to expand the number of areas in which integrative bargaining occurs. From that point of view, the matters involved in the AXA negotiation were typical negotiation items requiring a cooperative attitude.

In the same vein, Walton and McKersie note that existing attitudes have their influence on many aspects of the total collective bargaining relationship but perhaps especially on contract administration. Thus the number of matters of mutual concern not covered in detail by the contract, but on which there is nevertheless active consultation or collaborative administration, can differ radically depending upon the existing relationship pattern. That is why, for example, the union might participate in some activities, such as job evaluation, in cooperative relationships, while this would be less likely in competitive relationships. In both of our cases, the unions were largely involved in contract administration. At ECCE, the agreement significantly strengthened the ability of employees' representatives to oversee the restructuring process and be involved in its implementation. In particular, it allowed for the creation of a special works council committee with a wide range of tasks and competences, along with a social plan steering and monitoring committee that was to be set up at the appropriate time. As for AXA, union representatives influenced the internal mobility plan even after the agreement was signed. For example, union pressure was largely behind a new programme - not specified in the general agreement - that provided personalized training and support to less qualified and less self-confident employees. At each stage, before and subsequent to the signing of the agreement, union representatives contributed, through negotiation, to enriching mobility guidance devices. 


\subsubsection{Some potential impediments factors to integrative bargaining}

However, the presence of favourable conditions, such as cooperative attitudes, does not automatically imply that an integrative bargaining approach will actually prevail. There are a number of difficulties to be overcome.

\section{Intra-organizational bargaining}

One of the major obstacles that may hinder negotiation concerns the intra-organizational bargaining process. Intra-organizational bargaining deals with the conflict occurring within each negotiating party. In a negotiation, negotiators represent their constituents and may thus be analytically described as agents acting on behalf of their principal. As Walton and McKersie note, the organization participating in labour negotiations usually lacks internal consensus about the objectives they will attempt to obtain from negotiations. The degree of internal consensus mainly depends on the way the negotiators succeed in meeting the expectations of their principals, both regarding the negotiating objectives (substantive expectations) and the negotiating behaviour (behavioural expectations). The issue of intraorganizational bargaining, like the attitudinal structuring process, may interfere in many ways with distributive and integrative bargaining processes: very often, integrative bargaining is impeded by intra-organizational pressures that require negotiators to act in a specific way.

The authors note that union negotiators are probably subject to more organizational constraints than their management counterparts. The main reason for this is that unions are political organizations whose representatives are elected to office and in which contract terms must be ratified by an electorate. At this point it must be stressed that the French union landscape has some features that significantly heighten the acuteness of this issue. One of these is marked union pluralism, which manifests itself in competition or even conflict between trade unions. The contrasting ideological stances between unions not only hinder cooperation and the reaching of consensus, but they may also reduce the scope for one or any given union to adopt attitudes that will enable the integrative bargaining process. When unions adopt such an approach, they risk being blamed for being too compliant and of not acting in the interests of employees. This may weaken their position and, more generally, reinforce the intra-organizational bargaining-related impediments to an integrative bargaining process.

The AXA case clearly illustrates this. The achievement of an agreement was largely made possible by the dominant position of the CFDT in the AXA union landscape ('Without the CFDT nothing could have been done,' a management negotiator insisted in an interview). Nevertheless, while four out of six unions signed the agreement, the two others - including the local branch of the CGT - refused to do so and even threatened to force management to deal with restructuring issues through legal procedure. The latter also denounced the CFDT's attitude as too compliant. In this regard, it is significant that, after the agreement was signed, the CFDT became involved in promoting the mobility plan, distributing internal communication informing employees about the programme, and working to dissipate fears that may have arisen. Moreover, as we will see later, plural-union dimension of intraorganizational bargaining strongly influenced the features of the negotiation process itself.

Mixed-motive bargaining

In the ECCE case, the organizational bargaining process was dealt with in such a way that it did not appear a major constraint during the course of events. On the other hand, one of the major obstacles that had to be overcome by the negotiators was the difficulty of combining items that were inherently distributive with others that were inherently integrative. This difficulty is stressed indirectly by Cutcher-Gershenfeld (1994), who blames the interest-based model for requiring parties to use a purely integrative approach to negotiations at a time when some highly distributive issues are on the table (such as layoffs, plant closures and wage and 
benefits concessions). The presence of such distributive items seems unavoidable in restructuring negotiation. All restructuring processes, especially if they involve collective redundancies, necessarily lead to negotiations that include some inherently distributive items that will have to be addressed, such as redundancy payments. In that sense, even if full plant shutdown had been an alternative, the ECCE negotiation cannot be described as pure integrative bargaining. It could be referred to more appropriately as a situation of mixed bargaining, when the negotiating agenda involves significant elements of conflict and considerable potential for integration (Walton \& McKersie, 1965); or again a situation of 'mixed motive bargaining', namely a negotiation that is neither purely conflictual not purely cooperative but a mixture of both (Cutcher-Gershenfeld, 1994; Fells, 1998). Fells (1998) suggests that the mixed-motive pattern is common in industrial relations. However, the numerous difficulties associated with this pattern have also long been pointed out. For example, negotiators might find openness a real difficulty in the early stages of negotiation, knowing that the parties will eventually be engaging in competitive negotiation to close off the negotiation; or again, a negotiator adopting a mixed motive strategy may have the suspicion that 'cooperation' is just a ploy and that notwithstanding all the cooperative gestures on their part, the other side might really only be looking to maximize share (Walton $\&$ McKersie, 1965; Fells, 1998). Yet it should be stressed that the mixed-bargaining situation referred to by Walton \& McKersie has a more specific meaning in that it is viewed as a twostage process where the parties first engage in joint problem solving activities and then negotiate over how to divide the resulting gains from integrative bargaining. This approach to mixed bargaining is typically illustrated by the study by Bacon and Blyton (2007). Analysing negotiations to implement teamworking in the steel industry, they show that the gains for employees are the greatest when conflict tactics are used by union negotiators both in the joint-problem stage and in negotiation over the sharing of productivity gains

Finally, we analyse how the negotiators overcame these obstacles, which leads us to underline the fit between the design of negotiations and the kinds of problem faced by negotiators, and to define two different paths to achieving an integrative outcome.

\subsection{Achieving an integrative outcome: two different paths}

In the AXA and the ECCE cases, negotiations took place in two contrasting contexts, and negotiators faced very different difficulties in their attempt to reach an integrative outcome. In each case, the negotiating parties were inclined to privilege a cooperative relationship pattern, but many obstacles had to be overcome to translate this cooperative disposition into an integrative outcome. We will show how the features of the negotiation process in each case may be viewed as an appropriate response to the kinds of difficulty encountered.

Excluding intra-opponents by keeping the agreement tacit

In the AXA case, the main obstacle to be overcome was related to the intra-organizational bargaining sub-process. Walton and McKersie note that some unions refuse to record in writing some matters on which the parties reach agreement. With only an oral understanding, the membership does not receive reliable information about agreements reached during contract negotiations. This applied to the AXA negotiation. Even though the CFDT leading negotiators were disposed to recognize the potential joint-benefits of internal mobility, they were also aware that the issue of employment adjustment was highly sensitive, if not taboo, in the context of a wealthy company like AXA. They were therefore reluctant to portray the internal mobility programme as part of AXA management's commitment not to carry out redundancies and, more generally, as part of an underlying restructuring process. This 
reluctance to clearly define the employment adjustment process at stake in the agreement was a source of disagreement between the parties about the wording of the terms of the agreement. The final decision not to make the ultimate goal of the agreement explicit was driven by intraorganizational bargaining-related constraints, but it follows that the signed agreement lacked transparency. That is why two non-signatory unions refused to sign on the grounds that the agreement was a 'social plan in disguise' and demanded instead a clear statement of the level and structure of employment expected at the expiry date of the agreement. However, no significant action on their part was subsequently taken.

Bargaining over how to bargain

In the ECCE case, several elements contributed to lessen intra-organizational bargainingrelated pressures exerted on the union negotiators. First of all, at the beginning of events, the different local union branches set up an inter-union bargaining team. This team proved to be close-knit and well coordinated. More generally, the union negotiators benefited from the trust and strong support of the rank and file. This could be explained to a large extent by the personality of the actors - especially the CFDT leading negotiator, deputy secretary of the works council at the time, who had long won the esteem and trust of employees - and by a corporate culture characterized by a strong sense of belonging and community, which strengthened the solidarity between workers and their representatives ${ }^{6}$.

In this context, the major issue for the ECCE parties was related to the mixed-motive aspect of negotiation and its inherent difficulty in adopting an integrative bargaining approach while having to negotiate on some highly distributive items. A potential solution to these difficulties involves a preliminary dialogue about the negotiation process itself (Cutcher-Gershenfeld, 1994). This preliminary dialogue, also referred to as 'bargaining over how to bargain', may take the form of an explicit negotiation on the rules of the game that will govern the substantive negotiations to follow. The method agreement signed by the parties in the ECCE case illustrates the bargaining-over-how-to-bargain process. Method agreements correspond to a new legal device authorized, on an experimental basis, by the French Labour Code in 2002, then codified, but still on a non-compulsory basis, in 2005. Their general purpose is to plan the different stages of future negotiations and to facilitate the information and consultation process with the different work councils. The specific content of the method agreement signed by the ECCE parties was original and ambitious. It created the conditions for in-depth discussions by establishing a flexible schedule and setting up the provision of impartial information. Moreover, it increased the negotiating scope of employees' representatives. Apart from the chartered accountant at the disposal of the work council, as allowed by law, the agreement envisaged the possibility of resorting to independent experts. These independent experts, selected by employees' representatives and paid for by the company, were to be entrusted with the task of contributing to the discussion on the future of production in France, in particular by assessing production potential and identifying and studying new activities that could be developed. In addition, a mediation procedure, involving recourse to an external mediator, was envisaged in the event of persistent disagreement between the parties. During the course of negotiations, this mediation procedure was actually set in motion and the mediator played a helpful role in reaching an agreement. For instance, the many meetings he held with the ECCE shareholder probably helped to convince the latter of the need to send out a strong signal about his determination to maintain a factory in France, by publicly announcing an investment and modernization programme for the unit.

Beyond the formal planning of the different stages in future negotiation, a full bargainingover-how-to-bargain process may also be a way for the parties, first, to signal their willingness to adopt a cooperative approach, and second, to commit to not taking unfair

${ }^{6}$ On the management side, as well, negotiators benefited from the support of the sole shareholder who had clearly expressed his desire to avoid social conflict. 
advantage of the cooperative attitude from the other side, especially when dealing with distributive items. Several elements of the ECCE method agreement may thus be viewed as a way for the parties, especially management, to commit themselves to acting cooperatively. The management negotiator agreed that employees' representatives should propose the names of the independent experts and, if need be, the mediator, management being given only a right of veto (which was never exercised). In addition, one of the crucial points in the method agreement was a clause stating that a general agreement on the future redundancy programme was an obligatory condition to completing the procedure and, therefore, to being able to start the redundancy process. The acceptance of such a binding clause - despite objections from management's lawyer, who publicly advised the management negotiator against accepting it spoke volumes about management's confidence in its capacity to reach an agreement with employees' representatives. While indicating the level of pre-existing trust between the parties, this clause was also a strong signal sent by management that, in return, may have reinforced the employees' representatives' trust in the management negotiator.

Beyond the procedural arrangements it set out, the method agreement also stated explicitly the main goals of the negotiation and the spirit in which it was to be carried out. Its preamble, for instance, clearly expressed the parties' shared commitment to engage 'in a cycle of information and negotiation, aimed at bringing about an agreement on all the processes connected with the restructuring" and indicated that "the parties as of now state their determination to take all the necessary measures to defend and safeguard the professional future of all employees, as far as possible within - and failing this, if necessary, outside - the company'. The content of the method agreement thus reflected a shared ambition to seek a solution that would be perceived as legitimate and acceptable for both parties at the end of the procedure, after exploring alternative scenarios. The former leading union negotiator described the method agreement, during our interview, as 'first and foremost a project, a joint ambition, an objective, a mutual commitment to explore solutions'.

The signing of the method agreement and the subsequent negotiation point to one sharp contrast between the ECCE and AXA cases. Whereas the latter may be characterized by a certain lack of transparency as to the negotiation process and its ultimate purpose, the ECCE case represents a very structured and non-ambiguous negotiation process. In many aspects, and especially in consideration of the collective and organized reflection carried out in order to find alternative solutions to the plant shutdown, the ECCE case also presents a marked problem-solving dimension, consistent with the problem-solving model used by Walton and McKersie to characterize a pure integrative process. During the course of negotiations, all the internal and external actors involved carried out extensive, in-depth discussions about the diversification possibilities and about the role that a factory in France might continue to play in the ECCE overall strategy. This problem-solving approach had to be adopted at the same time as the parties had to negotiate on inherently distributive issues. In this respect, in addition to the mutual trust between the parties, the order of agenda items played a critical role. Indeed the negotiating parties were able to put off the negotiations over redundancy payments for as long as possible, focusing their energy on the measures intended to develop employment and to promote professional transitions for the workers to be made redundant. It should be noted that during the final discussion on redundancy payments a number of workers decided to go on strike for the first time. These strike actions, however, did not jeopardize what had been agreed previously. Furthermore, the fact of having dealt with this issue late in the negotiation process was not detrimental to the redundant employees, since the additional compensation was far higher than what has been awarded in similar contexts. 


\section{Discussion}

Restructurings are critical events for companies because they represent both a strategic and social upheaval. The empirical literature on the subject deals extensively with the need to focus on the social dimension, as the core of any restructuring, in order to avoid escalating resistance to its implementation, and hidden costs liable to compromise the economic success of the operation. Effective management of restructuring operations must recognize the need for a meditated, carefully-planned approach to the conditions under which they are negotiated.

\subsection{Negotiating restructuring projects: management issues}

Our contribution to the literature is to highlight the factors likely to lead to agreement on restructuring processes - an aspect which has, to our knowledge, been relatively little studied to date. Taking the French context - which has a markedly high incidence of conflict - we show that restructuring programmes can be negotiated, and lead to agreements. To do this, we undertook a detailed analysis of two very different restructuring cases: one a case of crisis restructuring and the other a proactive restructuring situation. In both cases, all parties agreed on the successful outcome at the end of the process, both economically (the companies' structures were adapted in accordance with management's wishes, at reasonable cost) and socially (salaried employees bore a lesser share of the cost of the adaptations than had been the case in past restructuring experiences, and their career paths were safeguarded, even revitalized).

\section{- Overcoming a unilateral approach to the restructuring decision}

Using Walton and McKersie's model, we were able to highlight some similarities between these two cases that were not, a priori, obvious. First and foremost, both restructurings were the object of genuine negotiation, and could not be classified as unilateral projects defined by management and imposed upon the trade unions and workers. Both processes evolved over time. This is a step forward compared with traditional, normative recommendations which tend to focus on safeguarding the restructuring process upstream by preparing the details well in advance of their announcement (Cameron, 1994). Agreement in restructuring processes is not only a question of content but of processes - a fact which reveals the misguided nature of the willingness to propose normative general principles designed to make restructuring projects 'effective' or 'ethical'.

In this context, a case-based study proved particularly fruitful, avoiding the reductive approach induced by quantitative studies of broader samples (Cameron et al., 1991) or conceptual, theoretical discussions unrelated to real-life scenarios (Van Buren, 2000). In both of the cases studied here, the negotiators were involved early in the process, and were able to discuss the reconfiguration of the company, as well as the organization of individual trajectories during the reconfiguration process. As a result, they were able to find solutions that would not be seen as a distributive trade-off, but as a common approach to the handling of a common issue, namely the long-term development, even the survival, of the business as a whole. In this context, the integrative aspect of the bargaining process is clearly highlighted: in one case (ECCE), the negotiators reached solutions that minimized the losses for all parties, and in the other (AXA), the restructuring delivered net surpluses for management and workers alike.

\section{- The conditions for integrative negotiations}

The cases also enable to clarify how such integrative bargaining processes can be put in place. One bargaining technique in particular can be highlighted. When negotiating events that are 
liable to result in job losses, the negotiators themselves need to feel secure in their roles, to avoid being drawn into the conflictual situations that were commonly observed. The Walton and McKersie model is particularly useful for describing and explaining the process and tactics of negotiations, and their development. In order to reach their contractual agreements, the negotiators benefited from a period of time in advance of the implementation of the adjustments, long enough for strategic or social alternatives to emerge and be explored. Beyond this, the negotiators were able to anticipate reactions that might have encouraged a dangerously radical approach on their part. This came about through a gradual structuring of attitudes, enabling mutual trust and respect to be established. We also noted the negotiators' favourable view of the ideology of compromise, but this inclination was developed and reinforced throughout the process, focusing discussion first and foremost on the future of the business - the essential prerequisite for long-term safeguarding of the individual career paths.

To achieve this, the negotiators were prepared to face difficulties connected with intraorganizational bargaining that may have forced the unions, in particular, to adopt more radical positions in response to the short-term preoccupations of the workforce. Two positions emerged: the first, adopted by AXA, involved keeping silent on the problems inherent in the restructuring process in order to concentrate the explicit agreements on the positive outcome of internal mobility. By doing this, the negotiating union, which was in a majority position, probably succeeded in neutralizing the rival union, which could have damaged the process as a whole by seeking to assert its position. The second position, adopted by ECCE, consisted of collectively and openly addressing the difficulties encountered by the company, and bargaining over how to bargain, preventing the negotiators and their principals from putting an early end to this common exploratory initiative.

Finally, in both cases, the actors proved to be able to remove themselves from a crisis context and establish procedures for bargaining and implementing workforce adjustments that reflected a certain continuity: this, too, emerged as a positive innovation in a situation where the negotiators usually tend to manage restructuring projects as quickly as possible (Sahdev, 2004).

\subsection{Theoretical contributions}

The Walton and McKersie model has, to our knowledge, seldom been used to deal with the problems associated with restructuring. While the authors themselves address the question of employment in the first examples of integrative bargaining results, they place the latter firmly in the context of an agreement intended to bring about changes to the regulations surrounding employment contracts in the long term. The AXA case illustrates this approach, in which the parties agreed to an approach that allowed them to settle problems relating to workforce adjustments by providing the means for secure internal mobility and employee support, through the maintenance of status and the affirmation of the voluntary participation of the people concerned.

The ECCE case is quite different, as it consists of a response to a clearly identified event (the termination of two large contracts by partner organizations). In this case, it is not possible to consider restructuring as an optional operation suggested by management and open to rejection. ECCE was in effect confronted with a serious crisis which, in the absence of a response, could lead to a complete halt in production. In this case, a purely distributive approach would not have maintained the status quo, but would have led to a loss of utility for both parties (bankruptcy and the loss of all jobs). Bargaining was unavoidable unless the 
closure of the factory was seen as an acceptable outcome. This type of situation is identified by Walton and McKersie as among those encouraging a significant change in attitudes moving towards a more cooperative approach and an enhanced recognition of the common aims and objectives of the different parties. In this case, the analysis of the evolution of the parties' utilities during the bargaining process could not be situated on continuum between the extremes of maintaining the status quo and forcing the passage of the restructuring measures, a situation in which either the workforce or the management obtains the greatest possible utility at the expense of the other party. Neither of these extremes could be countenanced, since both would lead to the disappearance of the business, and the total destruction of utility for both parties. In the case of ECCE, and for any business faced with a declining market, the approach can only be integrative. The zero sum game cannot be tolerated: there has to be either a positive or a negative outcome. While the Walton and McKersie model sees bargaining as a zero sum (distributive) or positive (integrative) option, the particular case of restructuring reveals a situation where the game could have a negative outcome in the absence of bargaining. Integrative bargaining will not necessarily result in the improvement of the positions of the two parties, but in the limitation of losses.

In addition, our study has enabled us to specify the role of conflict and risks induced by conflict. As stated by Bacon and Blyton (2007), cooperation is not systematically associated with satisfying results for both parties, especially for workers. They show that, in integrative bargaining processes, using conflict tactics is a way for unions to ensure that management will be inclined to make concessions, and hence improves workers' satisfaction. Our two case studies are consistent with this result. We have emphasized the role of attitudinal structuring as an enabling factor while also pointing out that conflict was explicitly evoked by unions as a threat, and that both parties had a common knowledge of what could have resulted from confrontational relations. We suggest that such a kind of threat played a dissuasive role and fostered cooperation and balanced gain (or loss) sharing.

\subsection{Limitations of the research, and implications for future research}

Based on an in-depth analysis of the two cases, their bargaining conditions and restructuring programmes, this research explores ways to safeguard the interests of both management and workers by adopting an integrative bargaining approach. The implications and significance of the results are subject to the methodological problems inherent in qualitative research in the field, carried out in situations with which the people involved may not feel comfortable. This led us to focus solely on situations described as 'innovative' by the protagonists themselves. As a result, we have few elements beyond general observations, or elements discussed in the literature, supporting a comparison of these cases to more archetypal situations that give rise to open conflict. This focus on positive cases may also have biased our analysis of the situations, despite the precautions we took. In semi-directive interviews, interviewees may have tried to highlight the positive aspects of their interactions rather than the darker areas. The cases and their similarities, however, do allow us to establish a basis for the definition of a safe process of restructuring for the different parties. This paper suggests a number of approaches that we hope will prove useful and productive for the qualification of all types of restructuring process according to the two key aspects identified: the safeguarding of the reorganization on the one hand, and the safeguarding of individual trajectories on the other. This contribution may be applied generally as the starting point for new, more confirmatory avenues of research, the conclusion of agreements and - beyond these - the success of restructuring operations. Conversely, it remains to be shown whether failed operations - for example, those ending in conflict and a deterioration of the positions of the two parties - are invariably characterized by the absence of integrative bargaining processes. We would posit, as a basis for future research, that a willingness to improve an organization to the detriment of 
its workforce, or a willingness to maintain the status quo for the workforce to the detriment of the structural adaptation process, will erode value in the long term for all parties concerned.

\section{References}

Amundson, N. E., Borgen, W. A., Jordan, S. \& Erlebach, A. C. 2004. Survivors of Downsizing: Helpful and Hindering Experiences. The Career Development Quarterly, (52): 256-271.

Andolfatto, D. (Ed.). 2004. Les syndicats en France. Paris: La Documentation Française.

Appelbaum, S. H. \& Close, T. G. 1999. Downsizing: an examination of some successes and more failures. Management Decision, 37(5/6): 424.

Bacon, N., \& Blyton, P. 2007. Conflict for Mutual Gains? Journal of Management Studies, 44(5): 814-834.

Brockner, J., Greenberg, J., Brockner, A., Bortz, J., Davy, J. \& Carter, C. 1986. Layoffs, equity theory, and work performance: Further evidence of the impact of survival guilt. Academy of Management Journal, (10): 233-250.

Brockner, J., Spreitzer, G., Mishra, A., Hochwarter, W., Pepper, L. \& Weinberg, J. 2004. Perceived Control as an Antidote to the Negative Effects of Layoffs on Survivors' Organizational Commitment and Job Performance. Administrative Science Quarterly, 49(1): 76-100.

Brockner, J., Wiesenfeld, B. M. \& Martin, C. L. 1995. Decision Frame, Procedural Justice, and Survivors' Reactions to Job Layoffs. Organizational Behavior \& Human Decision Processes, 63(1): 59-68.

Cameron, K. S. 1994. Strategies for Successful Organizational Downsizing. Human Resource Management, 33(2): 189-211.

Cameron, K. S., Freeman, S. J. \& Mishra, A. K. 1991. Best practices in white-collar downsizing : Managing contradictions. Academy of Management Executives, 5(3): 57-73.

Cascio, W. F. 2002. Strategies for responsible restructuring. Academy of Management Executives, 16: 80-91.

Cascio, W. F., Young, C. E. \& Morris, J. R. 1997. Financial consequences of employmentchange decisions in major US corporations. Academy of Management Journal, 40(5): 1175-1189.

Colin, T. \& Rouyer, R. 1996. La loi sur les plans sociaux face aux logiques gestionnaires: une portée limitée. Travail et emploi, (69): 5-22.

Collett, N. 2004. Shareholders and Employees: The Impact of Key Redundancies. Business Ethics: A European Review, 13(2-3): 117-126.

Cutcher-Gershenfeld, J. E. 1994. Bargaining over how to Bargain in Labor-Management Negotiations Negotiation Journal, (10): 323-335.

Dougherty, D. \& Bowman, E. H. 1995. The effects of organizational downsizing on product innovation California Management Review, 37(4): 28-44.

Eisenhardt, K. M. 1989. Building Theories from Case Study Research. Academy of Management Review, 14(4): 532-550.

Eisenhardt, K. M. \& Graebner, M. E. 2007. Theory Building From Cases: Opportunities and Challenges. Academy of Management Journal, 50(1): 25-32.

Feldman, D. C., Leana, C. R. \& Bolino, M. C. 2002. Underemployment and relative deprivation among re-employed executives. Journal of Occupational \& Organizational Psychology, 75(4): 453-471. 
Fells, R. E. 1998. Overcoming the Dilemnas in Walton and McKersie's Mixed Bargaining Strategy. Industrial Relations, 53(2): 300-325.

Friedman, M. 1970. The Social Responsibility of Business is to Increase Its Profits. The NewYork Times Magazine(33): 122-126.

Gazier, B. 2005. Comparing and evaluating national restructuring processes. Paper presented at the Monitoring Innovative Restructuring in Europe, Paris.

Greenhalgh, L., Lawrence, A. T. \& Sutton, R. I. 1988. Determinants of Work Force Reduction Strategies in Declining Organizations. Academy of Management Review, 13(2): 241-254.

Greenhalgh, L. \& Mckersie, R. B. 1980. Cost-effectiveness of alternative strategies for cutback management. Public Administration Review, 40(6): 575-584.

Greenhalgh, L., Mckersie, R. B. \& Gilkey, R. W. 1986. Rebalancing the workforce at IBM: a case study of redeployment and revitalization. Organizational Dynamics, 14(4): 3047.

Karake, Z. A. 1998. An examination of the impact of organizational downsizing and discrimination activities on corporate social responsibility as measured by a company's reputation index. Management Decision, 36(3/4): 206.

Leana, C. C. R. L. \& Feldman, D. D. C. F. 1988. Individual Responses to Job Loss: Perceptions, Reactions, and Coping Behaviors. Journal of Management, 14(3): 375389.

Mone, M. A., McKinley, W. \& Barker, V. L. 1998. Organizational decline and innovation : a contingency framework. Academy of Management Review, 23(1): 115-132.

Orlitzky, M. \& Schmidt, F. L. 2003. Corporate Social and Financial Performance: A Metaanalysis. Organization Studies, 24(3): 403-411.

Pettitt, J. \& Hanley, G. 2004. The effect of Enterprise Bargaining on Downsizing in the Australian Retail Banking Sector 1993-1998. Working Paper, Department of Management, Monash University(37/04).

Radin, T. J. \& Werhane, P. H. 2003. Employment-at-will, employee rights, and future direction for employment. Business Ethics Quarterly, 13(2): 113-130.

Ray, J.-E. 1995. Plan social et insécurité juridique. Droit social(7/8): 661-665.

Ray, J.-E. 2007. Droit du travail, droit vivant. Paris: Editions Liaisons.

Sahdev, K. 2004. Revisiting the survivor syndrome: The role of leadership in implementing downsizing. European Journal of Work and Organizational Psychology, 13(2): 165196.

Van Buren, H. J. 2000. The Bindingness of Social and Psychological Contracts: Toward a Theory of Social Responsibility in Downsizing. Journal of Business Ethics(25): 205219.

Walton, R. E., Cutcher-Gershenfeld, J. E. \& Mckersie, R. B. 2000. Strategic Negotiations. A Theory of Change in Labor Management Relations (Second ed.): Harvard Business School Press.

Walton, R. E. \& Mckersie, R. B. 1965. A Behavioral Theory of Labor Relations New-York: McGraw Hill. 